\title{
Luzes e sombras da cidade (São Paulo na obra de Mário de Andrade)*
}

\author{
Monica Raisa Schpun \\ Universitá degli Studi di Milano
}

\section{RESUMO}

Existe um repertório de imagens sobre São Paulo, constituído em pleno momento da "grande urbanização" e, em muitos casos, válido até hoje. Referindome a algumas das imagens mais recorrentes nos discursos da época sobre a cidade, examino, neste texto, sua presença na obra de Mário de Andrade, confrontando os sentidos em que aparecem nos dois registros.

Palavras-chave: São Paulo. "Grande urbanização”. Imaginário. Mário de Andrade.

\begin{abstract}
There is a report of images about São Paulo, wich was built up at the time of the "great urbanization" and which, in many cases, is still valid. In this article, I will look at some of the most recurrent images in the discourses about the city that appeared at the time and will examine their presence in the works of Mário de Andrade. I will also confront the different meanings that appears in the two registers.

Keywords: São Paulo. Great urbanization. Imaginary. Mário de Andrade.
\end{abstract}

São Paulo, a cidade macota lambida pelo igarapé Tietê Mário de Andrade, Macunaíma

O processo de urbanização paulistano, por sua velocidade e violência únicas, provocou e inspirou uma profusão de textos e narrativas. Reportagens, crônicas, ensaios, poemas, contos, romances: da pior à melhor literatura, a nova vida urbana deixou suas marcas nos mais variados vetores discursivos dos anos 10 e 20. Isto sem contar as representações visuais: na pintura e no incipiente cinema nascente também encontramos os ecos desse processo.

Porém, não se trata unicamente de um universo temático de inspiração. Tal abundância de discursos é, antes de mais nada, produto social do processo de urbanização. Pois o novo espaço urbano traz consigo a constituição de uma esfera pública de atividades, da qual fazem parte todas as formas de difusão de idéias e opiniões.

Efetivamente, a imprensa paulista e paulistana sofre, nestes anos de ur- 
banização, um desenvolvimento espetacular quanto ao número de títulos e às tiragens ${ }^{1}$, quanto à variedade dos periódicos propostos, quanto às técnicas de impressão, quanto à profissionalização cada vez maior e mais diferenciada de seus colaboradores (desenhistas, chargistas, ilustradores, redatores, cronistas) e quanto à rapidez cada vez maior no contato e na transmissão da informação. Esse fenômeno, que também atinge o mercado editorial, ainda que em menores proporções, responde diretamente não só pela publicação de novos livros, mas também pela sua difusão por outros meios de comunicação escrita, pelos comentários que podem suscitar, pelo debate que podem provocar ou ao qual podem estar reagindo.

Temos então, de um lado, inúmeras vozes que trazem ao domínio público a vida urbana e moderna. Mas a ressonância mesma de tais vozes, sua possibilidade de socializar-se depende da constituição simultânea de um espaço público de opiniões que é, por seu lado, fruto indissociável do processo de urbanização. Nesse sentido, além de inspirar a produção de discursos, a vida urbana transforma-se em foco dominante da vida social, ocupando lugar de difusor de idéias, de palco para debates e de espaço de decisões. E o novo espaço público aí criado serve de meio de promoção da própria urbanidade, que fala de si mesma. Assim sendo, a cidade, a um só tempo, seduz e transforma mentalidades. Ela está na origem de uma eclosão de discursos que espelham, com força particular, o impacto do urbano sobre o imaginário e as novas formas de sensibilidade coletiva nascentes, especificamente citadinas.

Existe um repertório de imagens sobre São Paulo, constituído em pleno momento da grande urbanização e, em muitos casos, válido até hoje. Ele exprime, sobretudo, um imaginário regionalista que elege São Paulo o cartão de visita do Brasil. A oligarquia do café ocupa aí uma posição chave. Seu sucesso e riqueza recentes ligam-se intimamente à política imigratória e ao boom demográfico paulistano. Assim, como beneficiários e artífices do processo de urbanização, os membros do grupo enxergam na nova cidade o reflexo por excelência de seu imaginário. A produção de discursos que se segue institui, então, uma memória social dominante, vitoriosa e otimista, essencialmente regida por uma lógica de progresso. Nesta, a cafeicultura aparece generalizada, como um feito de todos, e carregada de positividade: atores, relações e hierarquias sociais desaparecem atrás de um único agente, portador de progresso e de riquezas, "o paulista". Progresso e riquezas dos quais todo e qualquer brasileiro se beneficiaria, graças à generosidade desse mesmo "paulista”. Neste contexto, a grande cidade é o espelho perfeito de um imaginário social regionalista, inicialmente forjado pelas elites, mas socializado em seguida ${ }^{2}$.

Porém, quais são especificamente as imagens que, metaforizando positi- 
vamente a modernidade, como fruto e casa de chegada do progresso, constroem uma ligação privilegiada entre esta e a cidade de São Paulo, transformando tudo aquilo que é lido como moderno em obra e prerrogativa paulista? Referindo-me a algumas das imagens mais recorrentes nos discursos da época sobre a cidade, procurarei, neste texto, examinar sua presença na obra de Mário de Andrade, confrontando os sentidos em que aparecem nos dois registros. Assim, meu elenco de imagens abre-se com o Bandeirante, personagem extremamente presente em textos os mais variados durante toda a década de 20, e depois, no início dos anos 30, com a oposição das elites paulistas a Vargas, a Revolução de 1932 e a vitória eleitoral da "Chapa Única por São Paulo Unido!" nas eleições à Constituinte de 1933.

Todo o discurso dessas elites traz, na base, um regionalismo ferrenho. Assim, num primeiro momento, trata-se de explicar o sucesso do café pela natureza do paulista: forte, corajoso, empreendedor, desbravador dos interiores, alargador das fronteiras, o Bandeirante encarna aí o ascendente por excelência da população local, formador do verdadeiro caráter paulista, quatro séculos antes. Num segundo momento, já nos anos 30, a imagem é mais uma vez recuperada, num contexto diverso e a serviço de outros objetivos. Ainda que os princípios constitucionalistas, mobilizados contra Vargas, sejam originalmente fruto de tentativas de reconversão das elites, visando a recuperar espaços perdidos de poder, tal ideário chega a se popularizar em São Paulo. O paulista, herdeiro do Bandeirante, aparece então como lutador solitário à frente do País, vanguardista corajoso, pronto a tudo pela conquista de seus ideais, todos de justiça e de democracia. É assim que este rústico desbravador passa, da foice que abre fronteiras físicas, às armas que empurram para longe a ditadura, em benefício da democracia.

Porém, nos dois momentos, um duplo uso da metáfora Bandeirante existe. Por um lado, ela responde às aspirações de distinção das elites. Nesse sentido, "o" paulista não se refere a todo e qualquer paulista, mas somente aos "verdadeiros". Eis como a oligarquia cria a lenda de uma herança "quatrocentona ", que distingue suas famílias, ao mesmo tempo, das outras elites regionais, dos demais grupos sociais e, mais raro mas não menos significativo, de indivíduos ou famílias em ascensão ${ }^{3}$. As levas de estrangeiros recrutadas para o café ocupam, por sua vez, o papel de figurantes, de "braços para o café", caminhando, curvadas, atrás da figura altiva - e sempre alta — do líder Bandeirante, latifundiário. Por outro lado, metáfora fundamentalmente regionalista, a figura do Bandeirante serve perfeitamente aos esforços de coesão social, de construção de identidades coletivas locais. Aí, não existem mais verdadeiros nem falsos paulistas: todos aparecem unidos - em 1932, por exemplo, atrás do mesmo ideal —, quatrocentões, imigrantes e outros. 
Lê-se, assim, num dos inúmeros panfletos que circulam em São Paulo durante e após a Revolução de 1932, buscando criar e reforçar uma identidade regional, além de construir sua memória:

(...) "Bandeirismo paulista”. Esta lição, meu filho,

Seduz, prende e entusiasma a todo o brasileiro.

Procura, pois, saber esta lição com brilho.

E, si alguém te indagar: "De que Nação és filho?"

Responde, filho meu, responde: "Eu sou Paulista”! ${ }^{4}$

Num outro texto, escrito após a derrota Constitucionalista em 1932, como uma homenagem a São Paulo, o autor toma a defesa dos paulistas contra seus eventuais detratores:

(...) Não se esquecem os que se affligem com o progresso de S. Paulo de apregoar que a quarta parte do povo paulista descende de italianos, como se isso pudesse alterar, como elles pensam ou procuram fazer crer, a homogeneidade mental da população deste Estado ou influisse de qualquer maneira para uma classificação à parte, dos paulistas, no conjuncto da população brasileira.

Os filhos e netos de italianos, nascidos em São Paulo, são tão paulistas quanto os descendentes dos antigos bandeirantes. ${ }^{5}$

Em pleno espaço urbano paulistano, quatro referenciais se destacam para lembrar tal descendência. Em primeiro lugar, quanto à visibilidade, o grande Monumento às Bandeiras, desenhado por Victor Brecheret. Em segundo lugar, ali perto, também beirando o Parque do Ibirapuera, jaz o Obelisco, monumento-mausoléu aos heróis de 1932. Em terceiro lugar, impõe-se, em meio à Avenida Santo Amaro (zona sul da cidade), a enorme figura de Borba Gato, concebida por autor menos prestigioso, mas referencial não menos conhecido dos paulistanos. Enfim, em pleno centro, temos a Ponte das Bandeiras, eixo urbano que, devido às inúmeras transformações da cidade, tornou-se espaço socialmente desvalorizado, de menor visibilidade, e de fraco apelo ou poder identitário. Mas nem sempre foi assim...

A Ponte das Bandeiras foi construída para substituir, sobre o rio Tietê, a antiga Ponte Grande (século XVII), caminho obrigatório para quem saísse de São Paulo rumo ao Vale do Paraíba, a Minas (via Taubaté) e ao Rio de Janeiro, após passar pela precedente - e menor — Ponte Pequena, sobre o rio Tamanduateí. Com o aumento da circulação de automóveis no centro da cidade, a Ponte Grande tornou-se insuficiente. Sua substituição fez parte do "Plano 
de Avenidas", escrito em 1929 pelo então professor da Escola Politécnica, Francisco Prestes Maia, e realizado alguns anos mais tarde ${ }^{6}$. Prestes Maia planejou um "Sistema Y": as "pernas" seriam as Avenidas 9 de Julho e Itororó (depois 23 de Maio) que, vindas do sul, juntavam-se no vale do Anhangabaú. Este, de parque, viu-se transformado em corredor viário, ponto de partida para o norte, numa única via, a Avenida Tiradentes. A Ponte das Bandeiras, inaugurada em 25 de janeiro de 1942 (data do aniversário da cidade), durante a gestão do já então prefeito Prestes Maia (1938-1945), situa-se exatamente no ponto em que a Avenida Tiradentes chega ao rio Tietê, compondo assim a base do "Y". Vale notar, ainda, que 1942 é o ano do décimo aniversário da Revolução de 1932, e que os nomes dados às duas "pernas" do "Y" também se referem à data: 9 de Julho foi o dia inicial do movimento, e 23 de Maio, a data da manifestação na qual morreram os famosos quatro jovens: Martins, Miragaia, Dráuzio e Camargo - M.M.D.C.. Estes últimos são lembrados no espaço urbano pelo Obelisco que, inaugurado a 9 de julho de 1955, em homenagem ao $33^{\circ}$ aniversário da Revolução Constitucionalista, marca o outro extremo da mesma avenida 23 de Maio, e fica próximo do Monumento às Bandeiras.

Tanto do ponto de vista da visibilidade no espaço urbano, quanto da eficiência simbólica na utilização plástica de elementos identitários fortes, o Monumento às Bandeiras me parece exemplar. Foi encomendado, em 1936, a Brecheret, por Armando de Salles Oliveira (1887-1945), então governador de São Paulo. Político ligado ao PD, e depois ao Partido Constitucionalista, e um dos fundadores da UDN, Armando de Salles era genro de Júlio de Mesquita e membro do "grupo do Estado". Apesar de seu envolvimento com o constitucionalismo, trata-se de um nome de compromisso entre as elites paulistas e o governo Vargas. Em 1936, ele deixa o governo para candidatar-se à Presidência da República. O Estado Novo o surpreende, junto a seus aliados, até então convencidos da provável vitória paulista nas eleições de 1937 e do retorno do grupo ao centro da cena política nacional. Não há nada de gratuito no fato de que especificamente esse governador de São Paulo, durante a era Vargas, encomende a um dos nomes mais expressivos do modernismo local um "Monumento às Bandeiras”. Afora as intersecções reais entre o imaginário das elites político-econômicas paulistas e aquele de suas elites artístico-intelectuais ${ }^{7}$, interessa realçar aqui em que contexto preciso se faz este tão ambicioso apelo à imagem do Bandeirante, e com que fins. Assim, em mensagem enviada à Assembléia Legislativa, no quarto aniversário da Revolução de 1932, diz o governador, interpretando à sua maneira o projeto de Brecheret:

(...) Não há quem desconheça a concepção de Brecheret. É uma arrancada de Bandeirantes, para a conquista da Terra Virgem. (...) Tudo ali é força, movimen- 
to e ação. Alguns homens, ajudando com o braço a puxar o batelão, com o outro sustêm companheiros desfalecidos de fadiga ou de febre: é a solidariedade, indispensável para o triunfo. Dois bandeirantes, os chefes, vão na frente a cavalo: é o princípio da autoridade, o mais forte esteio da civilização que o comunismo tenta destruir. As figuras decrescem em tamanho: é a hierarquia, inseparável da disciplina, e um dos mais belos princípios da organização social, porque permite ao que está no ponto mais baixo ascender por si mesmo à posição mais alta. Na frente do grupo a grande figura da mulher que representa a terra virgem, em cuja conquista os bandeirantes partem, mostra que eles sabem o que querem e para onde vão: é o pensamento dominando a ação. Pela avenida Brasil, que dá acesso a todos os grandes caminhos de penetração — ao Tietê e às estradas que levam ao Sul, ao Mato Grosso, a Minas e a Goiás — saíram como sairão, grandes grupos de bandeirantes, que iniciarão uma nova etapa de sua obra, a serviço da Pátria. ${ }^{8}$

A leitura de Armando Salles põe de forma eloqüente, os bandeirantes mais uma vez em ação, trazendo-os ao presente ("saíram como sairão"). Porém, não se trata de uma continuidade desta ação: uma ruptura existe, marcando um novo tempo, "uma nova etapa". E, apesar de acreditar na ação de "grandes grupos de bandeirantes", o governador só vê dois deles no monumento de Brecheret, "os chefes". Falando de si mesmo, vendo-se na liderança política do País, ele fala também de disciplina, hierarquia, solidariedade antes de prever, em seguida, a ação anônima, por todos os caminhos, destes "grandes grupos de bandeirantes" que o monumento a seu ver anuncia. Paulistas que irradiarão, pelo País, sua força, mantendo-se à frente da nação, mas seguindo disciplinadamente seus chefes, estes sim, verdadeiros bandeirantes. A força do texto encontra-se na forma com que os dois usos da metáfora Bandeirante aparecem entrelaçados: a identidade regional, elemento de coesão, torna-se inseparável da hierarquia social. As duas se fortalecem e justificam mutuamente.

De que forma a imagem do Bandeirante, tão presente na história paulista, aparece na obra de Mário de Andrade? Atestando mais uma vez a importância da questão, os usos nem raros nem gratuitos que são feitos de tal figura, profundamente ancorada na memória e no espaço urbano paulistano, Mário insere sua óptica no debate. Óptica divergente, como veremos.

Particularmente presente na obra poética do autor, a imagem do Bandeirante integra, antes de mais nada, referências feitas à composição da população paulistana. Mário explora, simultaneamente, os dois eixos principais de utilização social da metáfora, assinalados acima. Em primeiro lugar, no 
sentido de desvendar e inverter lógicas constitutivas de um imaginário de coesão social, nas quais toda diversidade acaba achatada atrás de uma identidade única. Além disso, no sentido de desmontar uma memória social regionalista que justifica, antes de mais nada, distinções sociais (entre "verdadeiros" e "falsos" paulistas, segundo a posse de uma ascendência "quatrocentona" ou não). Como contraponto e pano de fundo a tudo isso surge, na poesia marioandradiana, o prosaico e complexo cotidiano urbano. Assim, em Paulicéia Desvairada, obra que acumula quase todas as referências ao Bandeirante, os exemplos são eloqüentes:

(...) Era uma vez um rio...

Porém os Borbas-Gatos dos ultra-nacionais esperiamente!

Havia nas manhãs cheias de Sol do entusiasmo

As monções da ambição...

$\mathrm{E}$ as gigânteas vitórias!

As embarcações singravam rumo do abismal Descaminho...

Arroubos... Lutas... Setas... Cantigas... Povoar!

Ritmos de Brecheret!... E a santificação da morte!

Foram-se os ouros!... E o hoje das turmalinas!...

_ Nadador! Vamos partir pela via dum Mato-Grosso?

_ Io! Mai!... (Mais dez braçadas.

Quina Mignone. Hat Stores. Meia de seda.)

Vado a pranzare com la Ruth. ${ }^{9}$

Ou ainda:

(...) Guardate! Aos aplausos do esfusiante clown,

Heróico sucessor da raça heril dos bandeirantes,

Passa galhardo um filho de imigrante,

Louramente domando um automóvel! ${ }^{10}$

E, enfim:

(...) Costureirinha de São Paulo,

Ítalo-franco-luso-brasílico-saxônica,

Gosto dos seus crepusculares,

Crepusculares e por isso mais ardentes,

Bandeirantemente! ${ }^{11}$ 
Ainda nessa mesma lógica, Mário insiste nos traços de diferenciação interna da população paulistana. A palavra-chave de Paulicéia Desvairada, "arlequinal “, presente em 11 dos seus 22 poemas, já indica a composição múltipla dessa população. Contudo, não se refere a uma eventual síntese que, recolhendo influências esparsas e diversas, crie algo novo mas homogêneo, uma identidade geral. A fantasia do arlequim compõe-se de losangos justapostos, de um conjunto de elementos que, colocados lado a lado, mantêm sua integridade sem fundirem-se uns aos outros, como parece desejar Antoine Renard, citado acima.

Além das diferenças, horizontais, Mário refere-se também às desigualdades. Pois o uso corrente da metáfora em questão visa a apagar, ao nível do imaginário, todas essas fronteiras constitutivas da ordem social, no sentido de melhor preservá-las. O poeta, por seu lado, trata-as em conjunto, mostrando que elas possuem nexos profundos umas com as outras e, além disso, que sem vê-las não poderemos perceber também as fissuras que as atravessam e constituem. Nesse sentido, retratando o corso carnavalesco da Avenida Paulista, palco por excelência do desfile das elites, tanto na avenida, quanto nas calçadas, espaço dos casarões, diz o poeta, que assiste ao espetáculo apertadamente, do bonde:

(...) Alturas da Avenida. Bonde 3.

Asfaltos. Vastos, altos repuxos de poeira

Sob o arlequinal do céu ouro-rosa-verde...

As sujidades implexas do urbanismo.

Filets de manuelino. Calvícies de Pensilvânia.

Gritos de goticismo.

$\mathrm{Na}$ frente o tram da irrigação,

Onde um Sol bruxo se dispersa

Num triunfo persa de esmeraldas, topázios e rubis...

Lânguidos boticellis a ler Henry Bordeaux

Nas clausuras sem dragões dos torreões...

Mário, paga os duzentos réis.

São cinco no banco: um branco,

Um noite, um ouro,

Um cinzento de tísica e Mário...

Solicitudes! Solicitudes! ${ }^{12}$

Num outro momento da obra, na voz dos “Orientalismos Convencio- 
nais ", coro de "As Enfibraturas do Ipiranga "Mário coloca justamente a imagem de São Paulo contra a qual se levanta, em querela que identifica aquela da própria escritura, entre "passadistas" e "modernos"13. Nesse paralelo, a cidade cosmopolita, irredutível a um denominador comum, serve de aliado perfeito e de metáfora privilegiada a toda iniciativa de ruptura, de heterodoxia, inclusive poética:

\section{(...) Somos os Orientalismos Convencionais!}

Os alicerces não devem cair mais!

Nada de subidas ou de verticais!

Amamos as chatezas horizontais!

Abatemos perobas de ramos desiguais!

Odiamos as matinadas arlequinais!

Viva a Limpeza Pública e os hábitos morais!

Somos os Orientalismos Convencionais!

Glória aos iguais! Um é todos! Todos são um só!

Somos os Orientalismos Convencionais! ${ }^{14}$

Em "Improviso do mal da América ", poema de Remate dos Males, Mário insiste de forma ainda mais radical nessa impossível coesão, evocando uma São Paulo em nada Bandeirante. Logo no início, vê-se que o poeta-narrador não tem ascendência imigrante. Mas aquilo que lhe dá sua terra não significa nada além do que os demais "ecos", vindos de outras partes:

(...) Eh coisas de minha terra, passados e formas de agora,

Não me completam mais que um balanço de tango,

Que uma reza de indiano no templo de pedra,

Que a façanha do chim comunista guerreando,

Que a prantina de piá, encastoado de neve, filho de lapão.

São ecos. Mesmos ecos com a mesma insistência filtrada

Que ritmos de síncopa e cheiro do mato meu. ${ }^{15}$

Sendo igualmente um receptáculo de influências diversas, São Paulo ocupa, lado a lado com o poeta, o papel de protagonista:

(...) Lá fora o corpo de São Paulo escorre vida ao guampasso dos arranhacéus,

E dança na ambição compacta de dilúvios de penetras

Vão chegando italianos didáticos e nobres; 
Vai chegando a falação barbuda de Unamuno

Emigrada pro quarto-de-hóspedes acolhedor da Sulamérica;

Bateladas de húngaros, búlgaros, russos se despejam na cidade...

- Coro? Onde se viu agora coro a quatro vozes, minha gente! -

São coros, coros ucranianos batidos ou místicos, Sehnsucht d'além-mar!

Home... Sweet home... Que sejam felizes aqui! ${ }^{16}$

Eis que a chegada dos "penetras", das "bateladas" de imigrantes, que dão vida e forma à cidade, implica a questão central do contato, do olhar mútuo e estrangeiro, estranho, trocado entre as partes. Pois o todos-por-um da ideologia Bandeirante, fabricada pelas elites, edulcora e elude, como fato menor - do outro - e passível de neutralização, as nuanças da convivência, a verdade dos conflitos próprios à experiência cotidiana da diferença:

(...) Trazem vodca na sapiquá de veludo

Detestam caninha, detestam mandioca e pimenta,

Não dançam maxixe, não dançam catira, nem sabem amar suspirando.

E de-noite monótonos reunidos na mansarda, bancando conspiração,

As mulheres fumam feito chaminés sozinhas,

Os homens destilam vícios aldeões na cantiga;

E como sempre entre eles tem sempre um que manda sempre em todos,

Tudo calou de sopetão, e no ar amulengado da noite que sua... ${ }^{17}$

E se os imigrantes têm sua leitura própria da sociedade que encontram, têm também sua visão sobre a ideologia Bandeirante da pureza de sangue, e sobre as estratégias de ascensão e integração social. Mário lhes dá a palavra, cheia de humor e ironia:

(...) Meu baralho tem dois ouros

Eu não quero mais jogar

Meu baralho dois ouros

Eu não quero mais jogar.

E diz o prinspo

Sangue-azul louro perneta

Ontem me deu na veneta

Fui na venda pra jogar

Joguei no sangue

Companheiro de aventura 
Mas o sangue se depura

Está na moda depurar

Meu baralho dois ouros

Eu não quero mais jogar.

E diz o sangue

Rebolando a raça fina

Tintinabulem tintinas

Que eu vou jogar no ariano

Mai' não me assustem

Que num mês viro paulista

Ganho bem suspendo a crista

E tenho quatrocentos anos. ${ }^{18}$

Enfim, opondo-se definitivamente à pretensa pureza Bandeirante, Mário refere-se à questão da hospitalidade do imigrante, à relação entre quem chega e quem já está. Para tal, recorre à metáfora tricolor da bandeira paulista — vermelha, preta e branca —, símbolo tantas vezes evocado pelas elites em 1932, verdadeiro brasão regionalista. Jogando com suas cores, o poeta subverte seu uso habitual:

(...) Grito imperioso de brancura em mim...

(...)

Me sinto branco, fatalizadamente um ser de mundos que nunca vi.

(...)

Mas eu não posso me sentir negro nem vermelho!

De certo que essas cores também tecem minha roupa arlequinal,

Mas eu não me sinto negro, mas eu não me sinto vermelho,

Me sinto só branco, relumeando caridade e acolhimento,

Purificado na revolta contra os brancos, as pátrias, as guerras, as posses, as

[preguiças e ignorâncias!

Me sinto só branco agora, sem ar neste ar-livre da América!

Me sinto só branco, só branco em minha alma crivada de raças! $!^{19}$

O poeta não se limita a ultrapassar, com o seu, o branco das listas da bandeira. Ele ultrapassa também o "branco relumeando caridade e acolhimento". Isto porque, na diversidade, ele busca aquilo que não encontra em sua terra. $\mathrm{Ou}$, ainda mais, aquilo que dê novos rumos a essa terra, que lhe traga renovação. Portanto, não se trata só de "acolhimento", mas de troca: 
(...) Me sinto branco, fatalizadamente um ser de mundos que nunca vi. Campeio na vida a jacumã ${ }^{20}$ que mude a direção destas igaras ${ }^{21}$ fatigadas E faça tudo ir indo de rodada mansamente Ao mesmo rolar de rio das aspirações e das pesquisas...

Não acho nada, quase nada, e meus ouvidos vão escutar amorosos

Outras vozes de outras falas de outras raças, mais formação, mais forçura.

Me sinto branco na curiosidade imperiosa de ser. ${ }^{22}$

Como vimos, o Bandeirante encarna bem, no imaginário das elites, a figura do desbravador, do pioneiro, daquele que, sem descanso, trabalha pelo enriquecimento do País. A metáfora é tão eficiente que acaba forjando uma identidade regional forte e duradoura. Entretanto, não se pode esquecer, a imagem por excelência do sucesso da oligarquia paulista é sua capital, São Paulo, expressão máxima do espírito empreendedor e progressista que o grupo pretende dar de si mesmo, da auto-imagem construída e propalada. E o Bandeirante, representado e lembrado em referenciais espaciais precisos, dentro do espaço urbano, também está por trás da forma dada a esse espaço durante a grande urbanização. Encarnando perfeitamente o agente da metropolização, ele toma parte ativa nesta formalização mais que perfeita do ideário dominante.

O principal título da imprensa de variedades paulistana da época, $\mathrm{A} \mathrm{Ci}$ garra, exprime de forma eloqüente a força dessa aspiração à modernidade $\mathrm{e}$ ao progresso urbano. Todo o esforço concentra-se na construção de uma representação visual de cidade moderna, espelho de um imaginário marcado pelos arranha-céus de Nova York e Chicago, pelas ruas de Paris e Londres, pelas lojas, cafés e teatros dos grandes centros europeus e americanos. Longas reportagens fotográficas trazem a crônica da expansão comercial da cidade, transformando em notícia acontecimentos como a abertura de novos estabelecimentos, ou mesmo as reformas que ampliam as instalações de alguns destes, adaptando-os a uma maior demanda e assinalando seu sucesso. Os equipamentos de lazer e o circuito da vida cultural, social e mundana são extremamente valorizados, como signos fortes de cosmopolitismo e de crescimento urbano. Além disso, um tal crescimento deve ser ressentido como de todos, socializando-se na "paulistanidade". ${ }^{23}$

A velocidade também participa dessa lógica, surgindo em inúmeras referências discursivas ao tráfego urbano, à circulação de automóveis, de bondes, à pressa dos transeuntes, enfim, a um novo ritmo que se quer ver impresso na cidade e que dela parece emanar. O automóvel aparece então como metáfora por excelência da modernidade e da urbanidade ${ }^{24}$. Seja em crônicas e artigos da imprensa, seja em textos literários, o impacto da velocidade tor- 
na-se tema constante, especialmente visível através de uma leitura do espaço urbano que ressalta a nova presença dos também novos meios de transporte.

As corridas de moto ou de automóvel e o início da aviação são acontecimentos espetaculares, atraindo um grande público. Sports, revista destinada a um público rico, e sobretudo masculino, reserva uma grande parte de seus artigos ao motociclismo, ao automobilismo e à aviação. Tais textos, extremamente técnicos, devem interessar principalmente aqueles que podem comprar motocicletas ou carros importados, possibilidade limitada a muito poucos. Dentre as publicidades da revista, as de concessionárias, lojas de acessórios ou empresas de manutenção mecânica também ocupam um espaço determinante, reforçando o tom elitista da revista, órgão oficial do Automóvel Club e da Sociedade Hípica Paulista, dois dos espaços mais seletos da sociabilidade paulistana. Por outro lado, os nostálgicos que, a partir da segunda metade da década de 20, começam a lamentar na imprensa o esvaziamento do Carnaval de rua, atestam na verdade a democratização da festa. A posse ou o aluguel de um automóvel, condição sine qua non para tomar parte no corso, torna-se pouco a pouco acessível a novas camadas da população, empurrando as elites para dentro dos salões, nos bailes fechados dos clubes ${ }^{25}$. Os discursos sinalizam então um contexto onde aspirações fortes de progresso tendem a encobrir o processo pouco linear das transformações. Apesar disso, se os novos ritmos e equipamentos impõem-se pouco a pouco no cenário urbano, eles impõem-se efetivamente, e talvez não suficientemente "pouco a pouco": sua aparição provoca o espanto e a admiração de que são fruto os textos em questão.

Enfim, a verticalidade também aparece como metáfora do crescimento da cidade, o crescimento para cima valendo quase mais que a expansão dos bairros, que o alargamento da superfície urbana. Nos primórdios do cinema paulista, esse mesmo anseio marca boa parte da produção, em tomadas que privilegiam elementos geométricos cortando a tela de alto a baixo, alongando neste sentido paisagens urbanas que aparecem estreitadas, além de serem freqüentemente vistas de baixo. Talvez aqueles que filmavam tenham incorporado o imaginário dominante; o que é certo, porém, é que estavam preocupados em responder ao gosto e às demandas de produtores e $\operatorname{críticos}^{26}$. Trata-se de um olhar que se generaliza: na imprensa e na literatura, as referências a arranha-céus e ao crescimento vertical da cidade também se multiplicam.

Quanto a isso, destacam-se a história e a presença urbana do prédio Martinelli. Construído pelo italiano Giuseppe Martinelli (Luca, 1870 - Rio de Janeiro, 1946), foi o mais alto edifício de concreto armado do mundo, numa época em que essa técnica de construção ainda estava se desenvolvendo para ir, aos poucos, transformando a paisagem arquitetônica paulistana. Algumas características do projeto e de seu processo de construção ilustram bem o ima- 
ginário não somente dos empreendedores da época, mas também da população de forma geral. Seu idealizador morava no Rio; apesar disso, para realizar seu sonho de arranha-céu, escolheu São Paulo, evidentemente não por acaso. Pois se em sua cidade natal, na Toscana, existia a tradição, dentre as famílias mais ricas, de erigir altas torres, símbolo de prestígio impresso no espaço urbano, tal prática social não foi transferida gratuitamente ao país de imigração. Esta encontrou aí um terreno favorável: o processo de urbanização paulistano. Assim, através de sua obra, o imigrante Giuseppe Martinelli acerta os ponteiros com suas raízes - e com seu desenraizamento - e expressa uma identificação mais profunda com a sociedade na qual está vivendo, percebendo e compactuando com sensibilidades coletivas do seu presente.

A construção começa em 1924, seguindo um projeto de edifício que prevê 14 ou 18 andares. Na época, São Paulo possuía um conjunto arquitetônico predominantemente baixo, com casas térreas e assobradadas, além de alguns prédios de 5 ou 6 andares que começavam a despontar nas áreas centrais ${ }^{27}$. Destacavam-se então as torres das igrejas, a da estação da Luz, além das chaminés das fábricas, nos novos bairros operários situados a leste e, como elemento paisagístico natural, o pico do Jaraguá. Fora isso, existia somente o "Sampaio Moreira ", com seus 14 andares ${ }^{28}$. Aliás, este teria sido o motivo principal das primeiras alterações dadas ao projeto inicial do Martinelli, anunciadoras dos sucessivos aumentos de altura que antecederam o resultado final, de 30 andares, em 1929.

A verticalidade, em si, parecia ser elemento suficiente para exprimir a imagem de metrópole buscada para São Paulo. Pois quanto ao estilo, a torre cor-de-rosa de Giuseppe Martinelli não rompeu com os cânones do ecletismo em voga, nem com os princípios até então reinantes de organização interna dos espaços ${ }^{29}$.

Em todos os exemplos dados, por trás do esforço empregado em reforçar os traços de transformação e de ruptura, insinua-se a vida pacata e provinciana da cidade, descortinando uma realidade muito menos homogênea, marcada pela convivência de ritmos, equipamentos e paisagens díspares. Uma tal convivência torna-se particularmente visível nas referências feitas a elementos da paisagem natural da cidade, colocados em paralelo ou em confronto com a nova paisagem arquitetônica e urbanística. Eis, assim, a fala eloqüente de Antoine Renard:

(...) Realmente, esta cidade, marulhenta de vida e semeada de arranha-céos, verdadeiro escrínio de bellezas architectonicas e esculpturaes, encanta e deslumbra, pelo seu conjunto artístico e sumptuoso, a todos que a contemplam. 
O asseio desta capital e a elevada distincção de seus habitantes ferem logo a vista do visitante extrangeiro, já acostumado á vida nas grandes metropoles da Europa.

Podemos affirmar que bem poucas cidades do Velho Mundo - e innumeras são as que conhecemos - a excedem em iluminação.

Observada, à noite, do alto de qualquer de suas interessantes collinas, a capital paulista dá-nos a idéa de um immenso amphitheatro, immerso num vasto oceano de luzes, cuja belleza ainda tem, a realçar-lhe o conjuncto, a bizarria dos innumeros annuncios luminosos, projectados dos cimos dos seus arranha-céos. Observada de dia, das mesmas alturas, as chaminés das suas innumeras fabricas, a confundirem os seus espessos pennachos de fumo com as nuvens que passam, lembram-nos Manchester, o maior parque industrial europeu. ${ }^{30}$

Pretendendo elogiar São Paulo, sua grandeza, Antoine Renard não poderia deixar de referir-se, e de maneira privilegiada, ao crescimento vertical da cidade. E o faz, falando da cidade "semeada de arranha-céos" (do alto dos quais são projetados os anúncios luminosos), além das chaminés das fábricas que, pela conotação de trabalho que imprimem à cidade, terra de bandeirantes, equiparam-se em significado - e não só em altura - às torres dos mesmos arranha-céus. Não se deve levar em conta, é verdade, o fato de que, em 1933, a cidade não era ainda realmente "semeada de arranha-céos “. A impressão geral, ressentida não só por este autor, mas por inúmeros testemunhos da época, é dada por uma cidade onde as construções que caracterizavam o antigo burgo foram realmente destruídas em ritmo acelerado nas primeiras décadas do século. Para exprimir o impacto de tais transformações, a figura das torres, quer sejam das fábricas ou dos prédios, parece não somente corresponder a um imaginário, mas também ilustrar uma percepção.

Entretanto, se o imaginário de uma metrópole voltada para o futuro imprime-se com força na narrativa de Renard, este acaba esbarrando numa referência ao quadro geográfico da cidade. E trai, então, a perspectiva do texto, elegendo, como mirante da cidade, ponto privilegiado para a sua observação, não as alturas do topo de algum dos "arranha-céos ", mas o alto das "interessantes colinas “. Ver de cima ainda é, assim, ver da colina. Como nos revela Renard, em 1933, as alturas naturais paulistanas ainda não tinham sido encobertas, nem ultrapassadas pelas alturas construídas e, no raciocínio deste admirador incondicional da cidade, esta ainda possui cumes naturais que servem de referencial espacial determinante.

Vejamos agora como Mário de Andrade trata a questão.

O registro é duplo. Em primeiro lugar, num momento de efusão moder- 
nista, Mário nos coloca numa falsa pista. No "Prefácio interessantíssimo" a Paulicéia Desvairada (1922), afirma:

\section{(...) Escrever arte moderna não significa jamais para mim representar a vida atual no que tem de exterior: automóveis, cinema, asfalto. $\mathrm{Si}$ estas palavras frequentam-me o livro não é porque pense com elas escrever moderno, mas porque sendo meu livro moderno, elas têm nele sua razão de ser. ${ }^{31}$}

Lendo isso, podemos pensar que palavras como "automóveis, cinema, asfalto ", apesar de serem vistas como elementos exteriores à "vida atual ", apresentam-se ao menos como sintomas da modernidade. Porém, a despeito de falar da cidade, de utilizar metáforas urbanas, o combate desenvolvido no "Prefácio" refere-se, antes de mais nada, ao campo da literatura, à defesa de uma escrita que se quer moderna. Assim, ao passarmos à poética do autor, em busca da cidade, os termos enunciados acima não somente não aparecem, como o tom é outro. Pois se "automóveis, cinema, asfalto" compõem uma imagem imediata e coletivamente reconhecida como sendo ligada à vida moderna, a relação do poeta com a modernidade urbana é outra. Na São Paulo de Mário, valores fortes da época, como a velocidade, a verticalidade, essa busca generalizada por signos de metropolização, já tratada acima, aparecem humanizados. E o que dá esse caráter humano ao processo de transformações em curso é que Mário busca justamente os sinais da convivência entre o novo e o antigo, nuançando a ruptura tanto em relação à paisagem urbana, quanto em relação ao tempo. O progresso linear deixando de ser uma meta, o tempo e os ritmos urbanos parecem escapar menos às mãos dos paulistanos:

(...) Careço de marchar cabeça levantada,

Olhar altivo pra frente...

Mas eu queria olhar à esquerda...

Bonita casa colonial

Cheinha mesmo de paisagem!

_ "Olhar altivo pra frente!"

O meu tenente

Não aprecia as casas coloniais. 
Porém o meu olhar blefa o tenente.

Olhou altivo pra frente

E batendo no quépi do soldado da frente

Fez esquerda-volver

E meigamente espiou a casa colonial. ${ }^{32}$

Referindo-se à violência do processo de urbanização, Mário traz à cena discursiva um de seus possíveis contrapontos:

(...) Mas a taba cresceu... Tigüeras agressivas,

Pra trás! Agora o asfalto anda em Tabatingüera.

Mal se esgueira um pajé entre locomotivas

E o forde assusta os manes lentos do Anhangüera.

Anhangá fantasmal, feito de tabatinga

Guincha, entrou pelo chão como o Anhangabaú.

E a alvura se tornou cimento-armado, é cinza,

Tinge a garoa Borba Gato Engaguaçu.... ${ }^{33}$

Enfim, o prédio Martinelli, cartão postal e metáfora por excelência da urbanização paulistana, não poderia estar ausente dessa leitura da cidade e de seus rumos:

(...) A cidade está mais agitada a meidia.

As ruas devastam minha virgindade

$\mathrm{E}$ os cidadãos talvez marquem encontro nos meus lábios.

Minha boca é o peixe macho e derramo núcleos de amor pelas ruas.

Que irão fecundar os ovários da vida algum dia.

Eu venho das altas torres, venho dos matos alagados,

Com meus passos conduzidos pelo fogo do Grã Cão!

Mas pra viver na cidade de São Paulo escondi na corrente de prata

A inútil semente do milho, a maniva,

E enroupei de acerba seda o arlequinal do meu dizer...

E agora apontai-me, janelas do Martinelli,

Calçadas, ruas, ruas ladeiras rodantes, viadutos,

Onde estão os judeus de consciência lívida?

Os tortuosos japoneses que flertam São Paulo?

Os ágeis brasileiros no Nordeste? Os coloridos?

Onde estão os coloridos italianos? Onde estão os turcomanos? 
Onde estão os pardais, madame la Françoise, Ergo, ego, Ega, égua, água, iota, calúnia e notícias,

Balouçantes nas marquesas dos roxos arranhacéus ? ${ }^{34}$

Aqui, Mário volta-se mais uma vez à questão da composição heterogênea da população paulistana. Sem qualquer ufanismo, traz um Martinelli que, junto aos demais elementos da "agitada" cidade, é testemunha de sua desumanização, e mesmo da perda de sua identidade múltipla, de todas aquelas influências que compõem o "arlequinal dizer" do poeta. Este dissocia elementos que, nos discursos correntes, aparecem sempre solidários, como a verticalidade e o cosmopolitismo paulistanos, expressões privilegiadas da modernidade urbana.

Enfim, a paisagem urbana também se humaniza em Mário, graças a recursos ao meio geográfico, ao clima e aos elementos paisagísticos naturais:

\section{(...) A manhã roda macia a meu lado}

Entre arranha-céus de luz

Construídos pelo melhor engenheiro da Terra.

Como ele deixou longe as renascenças do sr dr. Ramos de Azevedo!

De que valem a Escola Normal o Théâtre Municipal de l'Opéra

E o sinuoso edifício dos Correios-e-Telégrafos

Com aquele relógio-diadema made inexpressively?

$\mathrm{Na}$ Paulicéia desvairada das minhas sensações

O Sol é o sr. Engenheiro oficial. ${ }^{35}$

Esse olhar sobre a vida urbana que tende a humanizar suas transformações, seus ritmos, refere-se, antes de mais nada, a uma maneira particular de ver e de representar a modernidade paulistana. Trata-se de uma reflexão que, a meu ver, encontra seu momento mais eloqüente em Macunaíma. Pois ainda que o protagonista tenha nascido "no fundo do mato-virgem", filho da "índia tapanhumas", ${ }^{36}$ grande parte de suas aventuras passa-se em São Paulo. A obra é composta de 17 capítulos e um epílogo; desses, 11 desenvolvem-se em São Paulo (do $5^{\circ}$ ao $15^{\circ}$ ), sem contar algumas referências esparsas feitas à cidade em outros três ou quatro capítulos ${ }^{37}$. Nesta parte significativa do romance, as raízes e os hábitos indígenas de Macunaíma confrontam-se com a lógica da vida urbana, tecendo a trama da reflexão. A metáfora por excelência, utilizada por Mário, para falar dos hábitos e elementos citadinos que exprimem a modernidade, é "máquina ". Na maior parte das vezes, "máquina” re- 
fere-se a elementos especificamente urbanos e ligados à modernidade trazida pela urbanização. É o caso do emprego da palavra logo no primeiro contato de Macunaíma com São Paulo, quando o herói começa a decifrar as novidades. Aprende então, a cada vez, que aquilo que vê ou ouve não tem equivalente no mundo do "mato virgem", e que se trata de "máquinas":

(...) A inteligência do herói estava muito perturbada. As cunhas rindo tinham ensinado pra ele que o sagüi-açu não era sagüim não, chamava elevador e era uma máquina. De manhãzinha ensinaram que todos aqueles piados berros cuquiadas sopros roncos esturros não eram nada disso não, eram mas cláxons campainhas apitos buzinas e tudo era máquina. As onças pardas não eram onças pardas, se chamavam fordes hupmobiles chevrolés dodges mármons e eram máquinas. Os tamanduás os boitatás as inajás de curuatás de fumo, em vez eram caminhões bondes autobondes anúncios-luminosos relógios faróis rádios motocicletas telefones gorjetas postes chaminés... Eram máquinas e tudo na cidade era só máquina! $!^{38}$

Assim, no início, tudo de desconhecido que encontra na cidade, e que se destaca diante de seus olhos, lhe é explicado como sendo um certo tipo de "máquina”, com um nome específico e, para ele, novo: "máquina telefone”, "máquinas jornais", "máquina automóvel”, "elétricos”, “táxis”, "bonde”, "aeroplano”, além da "máquina London Bank” e da "máquina luz elétrica”.

Entretanto, em alguns casos, a metáfora da máquina, que o protagonista emprega para nomear aquilo que lhe parece estranho e típico da vida na cidade, extrapola o urbano para metaforizar a "civilização". Por exemplo, as armas de fogo: "máquina garrucha”, “máquina revolver”, "máquina patek”, "máquina smith-wesson”; mas também "máquina negócios” e "máquina óculos de tartaruga"; no contato do herói com as mulheres, a "máquina ruge" abre a lista de outras tantas "máquinas": "meia-de-seda", "combinação", "cinta”, "decoletê", "mitenes”, “sapatos”, "roupa”, "repuxos”. Apesar disso, a relação de Macunaíma com elementos da modernidade e da "civilização" fazem-se durante sua estada em São Paulo. A vida urbana é o meio de acesso à "civilização" que passa, também, pelos signos da modernidade. E se tanto os hábitos e objetos "civilizados", quanto os equipamentos urbanos impressionam o herói, o que assusta mesmo são os elementos da modernidade, a Máquina:

(...) O herói aprendendo calado. De vez em quando estremecia. Voltava a ficar imóvel escutando assuntando maquinando numa cisma assombrada. Tomou-o um respeito cheio de inveja por essa deusa de deveras forçuda, Tupã fa- 
manado que os filhos da mandioca chamavam de Máquina, mais cantadeira que a Mãe-d'água, em bulhas de sarapantar.

Então resolveu ir brincar com a Máquina pra ser também imperador dos filhos da mandioca. Mas as três cunhãs deram muitas risadas e falaram que isso de deuses era gorda mentira antiga, que não tinha deus não e que com a máquina ninguém não brinca porque ela mata. A máquina não era deus não, nem possuía os distintivos femininos de que o herói gostava tanto. Era feita pelos homens. Se mexia com eletricidade com fogo com água com vento com fumo, os homens aproveitando as forças da natureza.

Macunaíma passou então uma semana sem comer nem brincar só maquinando nas brigas sem vitória dos filhos da mandioca com a Máquina. A Máquina era que matava os homens porém os homens é que mandavam na Máquina... Constatou pasmo que os filhos da mandioca eram donos sem mistério e sem força da máquina sem mistério sem querer sem fastio, incapaz de explicar as infelicidades por si. Estava nostálgico assim. Até que uma noite, suspenso no terraço dum arranhacéu com os manos, Macunaíma concluiu:

_ Os filhos da mandioca não ganham da máquina nem ela ganha deles nesta luta. Há empate. ${ }^{39}$

Porém, o empate não parece suficiente para tranqüilizar o herói, que continua:

(...) Não concluiu mais nada porque inda não estava acostumado com discursos porém palpitava pra ele muito embrulhadamente muito! Que a máquina devia de ser um deus de que os homens não eram verdadeiramente donos só porque não tinham feito dela uma Iara explicável mas apenas uma realidade do mundo. De toda essa embrulhada o pensamento dele sacou bem clarinha uma luz: Os homens é que eram máquinas e as máquinas é que eram homens. Macunaíma deu uma grande gargalhada. Percebeu que estava livre outra vez e teve uma satisfa mãe. Virou Jiguê na máquina telefone, ligou pros cabarés encomendando lagosta e francesas. ${ }^{40}$

Macunaíma liberta-se, a um só tempo, de suas preocupações a respeito da máquina, e do poder desta, quando imagina uma solução em que homem e máquina não mais empatam, mas se equivalem, a ponto de tornarem-se intercambiáveis. A origem do medo da máquina, ressentido pelo herói, está no fato de que os homens não teriam dado a esse invento uma forma narrativa, mítica ("uma Iara explicável"), mas aquela de uma "realidade no mundo", com uma vida independente da de seus criadores. Estes se encontrariam, assim, privados de qualquer poder sobre a criatura. Acrescentando à relação ho- 
mem-máquina um elemento mágico, lúdico, Macunaíma perde o medo: se a máquina parecia-lhe um deus, e se os homens pareciam-lhe falsamente dirigir esse seu invento, tudo se resolve com a certeza de poder ser máquina, e de ver a máquina como homem. Os elementos da modernidade, assustadoramente dominantes, que se desenvolvem sem controle humano tornam-se, então, não somente inofensivos, mas sobretudo humanizados, já que "as máquinas é que eram homens".

Todas as questões tratadas até aqui, dos sentidos em que São Paulo desponta na obra de Mário, desde a metáfora do Bandeirante, até aquela da máquina, reaparecem ainda nos escritos tardios do autor, mas de forma bastante diversa. Já no título de sua última obra poética — Lira Paulistana —, publicada postumamente, São Paulo ocupa o centro da cena. Porém, os debates dos anos vinte e trinta, quanto à população paulistana, o imaginário de suas elites e a modernidade, surgem, neste último olhar sobre a cidade, num registro sombrio e desiludido. Interessa notar, apesar disso, que alguns elementos sinalizadores da especificidade e da identidade de São Paulo fazem-se presentes.

Chama a atenção, antes de mais nada, o tratamento dado ao rio Tietê, especialmente no último poema da obra, "A Meditação sobre o Tietê". Tratase de imagem extremamente rica de um rio que, como os bandeirantes, penetra na terra em direção ao interior, afastando-se da costa e do oceano:

(...) Meu rio, meu Tietê, onde me levas?

Sarcástico rio que contradizes o curso das águas

$\mathrm{E}$ te afastas do mar e te adentras na terra dos homens,

Onde me queres levar?...

Por que me proíbes assim praias e mar, por que

Me impedes a fama das tempestades do Atlântico

$\mathrm{E}$ os lindos versos que falam em partir e nunca mais voltar?

Rio que fazes terra, húmus da terra, bicho da terra,

Me induzindo com a tua insistência turrona paulista

Para as tempestades humanas da vida, rio, meu rio!...

Ondas, a multidão, o rebanho, o rio, meu rio, um rio

Que sobe! Fervilha e sobe! E se adentra fatalizado, e em vez

De ir se alastrar arejado nas liberdades oceânicas,

Em vez se adentra pela escura e ávida dos homens, ${ }^{41}$

"Turrona" ou não, a insistência aparece como traço da "paulistanidade": insistência conquistadora, alargadora de fronteiras, de quem se adentra pelos interiores. Aqui, contudo, mais uma vez, a representação marioandradiana 
subverte o discurso corrente. Pois uma tal imagem, na boca das elites que se pensavam e se queriam bandeirantes, seria motivo de ufanismo, de orgulho, argumento de distinção social, além de metáfora para um certo espírito de liberdade, tido como traço de caráter inato ao "verdadeiro" paulista, viajante e desbravador por excelência dos confins. Já na voz do poeta, o mesmo Tietê funciona como metáfora da prisão em que se encontra:

(...) É noite. E tudo é noite. Debaixo do arco admirável

Da Ponte das Bandeiras o rio

Murmura num banzeiro de água pesada e oliosa.

Água noturna, noite líquida, afogando de apreensões As altas torres do meu coração exausto. De repente

O ólio das águas recolhe em cheio luzes trêmulas, É um susto. E num momento o rio

Esplende em luzes inumeráveis, lares, palácios e ruas, Ruas, ruas, por onde os dinossauros caxingam

Agora, arranhacéus valentes donde saltam

Os bichos blau e os punidores gatos verdes, Em cânticos, em prazeres, em trabalhos e fábricas, Luzes e glória. É a cidade.... É a emaranhada forma Humana corrupta da vida que muge e se aplaude. E se aclama e se falsifica e se esconde. E deslumbra. Mas é um momento só. Logo o rio escurece de novo, Está negro. As águas oliosas e pesadas se aplacam

É noite...Rio! Meu rio! Meu Tietê!

É noite muito... As formas... Eu busco em vão as formas

Que me ancorem num porto seguro na terra dos homens.

É noite e tudo é noite. O rio tristemente

Murmura num banzeiro de água pesada e oliosa.

Água noturna, noite líquida... Angúrios mornos afogam

As altas torres do meu exausto coração.

(...). Não tem formas nessa noite, e o rio

Recolhe mais esta luz, vibra, reflete, se aclara, refulge,

E me larga desarmado nos transes da enorme cidade. ${ }^{42}$

Se o rio não conduz o poeta até o oceano libertador, afastando-o dos interiores, e mesmo da cidade, ele ao menos poderia assegurá-lo na cidade. Debruçado sobre a Ponte das Bandeiras, em pleno coração paulistano, o poeta 
afoga-se no breu da noite, refletida em todo seu negrume, nas águas do rio. As luzes da cidade não parecem iluminá-lo, exceto durante o rápido instante em que o rio as recolhe, refletindo todo o brilho da metrópole. Vistas nas águas do rio, "luzes e glória", que caracterizam a cidade, parecem salvar o poeta. Mas tudo não passa de um flash e a escuridão mais uma vez o envolve. O rio, tão paulista, abandona-o "desarmado nos transes da enorme cidade". A mesma cidade que, em tantos outros poemas anteriores, era íntima do poeta, até de um ponto de vista físico, num encontro corporal.

O poeta só, abandonado e desarmado na escuridão da noite paulistana. Escuridão que nem as luzes desta chegam a clarear, e que o rio recusa-se a refletir. É o que resta de todas as imagens e metáforas da cidade, é o que vem por último, fechando a relação de Mário, poucos meses antes de sua morte, com São Paulo ${ }^{43}$. É o que o poeta escolhe deixar, como discurso sobre sua cidade, em contraponto às leituras correntes, ainda entusiasmadas, otimistas, ufanistas e regionalistas. Enroscado em um modelo de modernidade do qual discorda, desiludido com os rumos da cidade e vendo-se por ela abandonado, naquilo que chegou a aspirar, Mário despede-se. E, justamente por não ser o último a sair, apaga as luzes, antes de abandonar o debate.

\section{NOTAS}

* Artigo originalmente publicado em Rivista di Studi Portoghesi e Brasiliani, II, Pisa/Roma, Istituti Editoriali e Poligrafici Internazionali, 2000, pp. 105-123. Uma versão deste artigo foi apresentada durante o XII Congresso Internacional da Associação de Historiadores Latino-americanistas Europeus (AHILA), no Porto, em setembro de 1999.

${ }^{1}$ (...) quase 500 jornais e revistas foram fundados somente entre 1920 e 1929. Em 1912, São Paulo detinha o primeiro lugar nacional quanto ao número de periódicos publicados (incluindo o Distrito Federal na comparação). Ainda detinha a liderança em 1930, quando ocupava o segundo lugar nacional no que se refere ao número de pessoas empregadas no jornalismo, o primeiro lugar cabendo ao Distrito Federal. Entre 1911 e 1929, praticamente dobrou o número de jornais diários em São Paulo, atingindo um total de 66, superior à circulação em qualquer outro Estado da Federação e representando o dobro dos que eram publicados no Distrito Federal". Joseph Love, A Locomotiva: São Paulo na federação brasileira 1889-1937, Rio de Janeiro: Paz e Terra, 1982, p. 130.

${ }^{2}$ Em outros textos, trabalhei a questão da penetração dessa memória dominante na reflexão e na expressão discursiva de artistas e intelectuais. Estes, muitas vezes empolgados pelo processo de urbanização, pensam encontrar aí uma ruptura definitiva, e portanto carregada de utopia, em relação à sociedade agrária e oligárquica que sonham superar. A produção ensaística dos anos trinta é, nesse caso, um exemplo eloqüente. Ver, sobre isso, as reflexões já desenvolvidas em "Raízes do Brasil: o passado descortinando o presente", 
texto apresentado no seminário "Raízes do Brasil” (Centro de Estudos Brasileiros, Embaixada do Brasil em Roma, 30 de outubro de 1997) e "Ratos mansos, cidades sem raízes", Atas do encontro do grupo de trabalho Clíope, Porto Alegre, setembro de 1998, Editora da UFRS, no prelo. Ver também as reflexões de Mariza Corrêa sobre Casa-Grande \& Senzala, e a longa duração de alguns conceitos em: "Repensando a família patriarcal brasileira", $\mathrm{Ca}$ dernos de pesquisa, Fundação Carlos Chagas, 37, maio de 1981, pp. 5-16. Retomei tais reflexões, no sentido da penetração de uma memória dominante construída pela oligarquia do café, em Les Années folles à São Paulo: hommes et femmes au l'explosion urbaine (19201929). Paris: L'Harmattan/IHEAL, 1997, pp. 38-40, e “O Amor na literatura. Um exercício de temps de compreensão histórica”, Cadernos Pagu — Gênero, narrativas, memória, 8/9, 1997, pp. 177-209.

${ }^{3}$ Sobre a recuperação do mito do Bandeirante ver Katia Maria Abud, O Sangue intimorato e as nobilíssimas tradições (a construção de um símbolo paulista: o Bandeirante), tese de Doutorado, USP, 1985. Mais especificamente, sobre as estratégias identitárias da elite cafeicultora e o uso feito, neste caso, da imagem do Bandeirante, ver Sandra Pesavento e Mônica Raisa Schpun, "São Paulo et Porto Alegre: une approche comparée de l'histoire urbaine”, Histoire et sociétés de l'Amérique latine, ALEPH/Paris VII, nº 4, maio de 1996, pp. 110-112.

${ }^{4}$ Trechos inicial e final do poema "Non ducor duco". Segundo referência impressa no panfleto, trata-se de poema da obra A Epopéia das Bandeiras, de Indio Tamoyo Prado. Panfleto, s/d.

${ }^{5}$ Antoine Renard [pseud. Delcides Carvalho], São Paulo é isto! A riqueza economica de S. Paulo. A alma cívica paulista. A epopéa das bandeiras. São Paulo: janeiro de 1933, p. 74.

${ }^{6}$ Estudos de um plano de avenidas para a cidade de S. Paulo. São Paulo: Ed. Melhoramentos, 1930 .

${ }^{7}$ Problemática já abordada em “Os Trópicos e a tristeza do viajante”. Atas do Seminário Internacional "Literatura e História: diálogos convergentes?", Campos do Jordão, agosto de 1997, no prelo.

${ }^{8}$ Mensagem do governador Armando de Salles Oliveira apresentada à Assembléia Legislativa de São Paulo a 9 de julho de 1936. São Paulo, Revista dos Tribunais, 1936, p. 119. Citado por Ilka Stern Cohen, "Para onde vamos?" Alternativas politicas no Brasil (1930-1937), tese de Doutorado, USP, 1997, pp. 225-227.

${ }^{9}$ Mário de Andrade, “Tietê”, poema de Paulicéia desvairada (1922). In: Poesias completas (edição crítica de Diléa Zanotto Manfio), Belo Horizonte/São Paulo: Itatiaia/EDUSP, 1987, p. 87. Todas as citações da obra poética do autor feitas a seguir referem-se a esta edição.

10 “O Domador", idem, p. 92.

11 “Tu”, idem, p. 98.

12 “O Domador", idem, p. 92. Vale notar aqui as referências aos traços arquitetônicos dos casarões da Avenida Paulista, com suas múltiplas influências, seu rebuscado, suas "sujidades implexas", e a simultânea tranqüilidade dessas "clausuras sem dragões nos torreões", 
onde um ar de preguiça, de languidez ensolarada parece caracterizar mais seus moradores do que a pretensa natureza guerreira, habitualmente emprestada do Bandeirante aos "chefes" paulistas.

13 "Os Orientalismos Convencionais - (escritores e demais artífices elogiáveis)", em oposição às "Juvenilidades Auriverdes — (nós)”. Cf. “As Enfibraturas do Ipiranga”, "Distribuição das vozes”, idem, p. 103.

14 “As Enfibraturas do Ipiranga”, idem, p. 106.

15 "Improviso do mal da América" (1928), idem, p. 265.

${ }^{16}$ Idem, p. 266.

${ }^{17}$ Idem, p. 266.

18 “II", poema de O Carro da Miséria, idem, p. 284.

19 “Improviso do mal da América”, idem, pp. 265-267.

20 "Remo indígena, em forma de pá" (Novo Dicionário Aurélio da Língua Portuguesa).

${ }^{21}$ Embarcação, na origem: “canoa pequena e esguia, feita de casca de árvore” (idem).

22 “Improviso do mal da América." In: Mário de Andrade, op. cit., p. 266.

${ }^{23}$ Uma outra revista, circulando irregularmente durante os anos vinte, Ariel, e apresentando um projeto editorial que muda no decorrer da década, publica reportagens fotográficas exatamente no mesmo estilo e tom de A Cigarra, sobre os "progressos" da cidade. Porém, trata-se, de um modo geral, de publicação mais luxuosa, com melhor qualidade gráfica, de ilustrações e de reproduções fotográficas.

${ }^{24}$ Além de reunir outras tantas conotações: desde símbolo de ascensão social até prova de virilidade e demonstração de força. Brás, Bexiga e Barra-Funda, de Antônio de Alcântara Machado (1927) é, sobre isso, um ótimo exemplo. Dos 10 contos que compõem a obra, 6 apresentam referências à questão. Em "Gaetaninho", a admiração pelo automóvel mistura-se aos atropelamentos e acidentes de bonde tão freqüentes em São Paulo no início do século; em "Carmela” tem-se o aspecto sedutor do automóvel, trunfo considerável para um rapaz na conquista de uma moça; em “Tiro de Guerra n⿳0 35”, o protagonista é um cobrador de ônibus; em "A Sociedade", o automóvel é, ao mesmo tempo, símbolo de ascensão social do imigrante e trunfo de sedução; em "Lisetta", a maior parte do conto desenrola-se dentro de um bonde; em "O Monstro de Rodas”, moça é assassinada por rapaz dentro do carro.

${ }^{25}$ Cf. Maria Isaura Pereira de Queiroz, Carnaval brasileiro - o vivido e o mito. São Paulo: Brasiliense, 1992, prólogo.

${ }^{26}$ Filmes como "São Paulo, a sinfonia da metrópole" e "Fragmentos da vida", ambos de 1929, ilustram bem tal tendência. Cf. Rubens L.R. Machado Junior, São Paulo em movimento: a representação cinematográfica da metrópole nos anos 20, mestrado, USP, 1989.

${ }^{27}$ Por exemplo, o edifício Riachuelo, construído em 1917 por Cristiano Stockler das Neves, na Rua Libero Badaró, esquina com Ladeira Dr. Falcão (6/7 andares). 
${ }^{28}$ Construído pelo mesmo Cristiano Stockler das Neves na Rua Libero Badaró, número 336.

${ }^{29}$ Os dados aqui apresentados, sobre o Martinelli e seu idealizador, foram tirados de: Maria Cecília Naclério Homem, O Prédio Martinelli: a ascensão do imigrante e a verticalização de São Paulo. São Paulo: Projeto, 1984.

${ }^{30}$ Antoine Renard, op. cit., pp. 14-15.

${ }^{31}$ Mário de Andrade, op. cit., p. 74.

${ }^{32}$ Poema "IX”, de Losango Cáqui. In: idem, p. 130.

${ }^{33}$ Poema “X”, “Tabatingüera”, de Losango Cáqui. In: idem, p. 130.

34 “Dor” (15.X.33), poema de A Costela do grã cão (“Grã cão do outubro”). In: idem, p. 318.

${ }^{35}$ Poema "XXII", de Losango Cáqui. In: idem, p. 138.

${ }^{36}$ Mário de Andrade, Macunaíma: o herói sem nenhum caráter. Belo Horizonte/Rio de Janeiro: Villa Rica Editoras Reunidas Ltda., 1997, p. 9. Todas as citações da obra, feitas a seguir, foram tiradas desta edição.

${ }^{37}$ Trata-se dos capítulos 3, 4 e 16. No capítulo 17, sem referir-se especificamente a São Paulo, Macunaíma reflete sobre a possibilidade de "morar na cidade da Pedra". Cf. idem, p. 123.

${ }^{38}$ Idem, p. 30. O termo "máquina” aparece 52 vezes no texto. Por duas vezes o autor emprega também o termo "maquinando".

${ }^{39}$ Idem, pp. 30-31.

${ }^{40}$ Idem, p. 31.

${ }^{41}$ Mário de Andrade. Poesias completas, op. cit., pp. 387 e 393.

${ }^{42}$ Idem, pp. 386, 391-392.

${ }^{43}$ Mário de Andrade morreu em 25 de fevereiro de 1945. "A Meditação sobre o Tietê" foi escrito entre 30 de novembro de 1944 e 12 de fevereiro de 1945.

Artigo recebido em 8/2003. Aprovado em 10/2003. 